\title{
Naiskangelased korea müütides ${ }^{1}$
}

\begin{abstract}
Jinseok Seo
Teesid: Artikli eesmärgiks on analüüsida korea müütide struktuuri, tuua välja naiste kangelaslikkus, mis sisendas tolleaegsetesse sookaaslastesse vaprust ja lootust, ja seeläbi tõestada, et korea müüdid pole ainult ühiskonnas valitseva olukorra passiivne peegeldus, vaid neil on aktiivne funktsioon, mis avaldab ühiskonnale kindlat mõju ja korraldab ebaloogilist ühiskondlikku rühmitumist. Lisaks uurib artikkel korea naiste kangelaslikkust ilu ja väärikust väärtustavates müütides.
\end{abstract}

Märksõnad: chonsol (legend), Korea, Korea suuline kirjandus, mindam (muinasjutt), müüdikangelane, šamanism, šinhua (müüt).

\section{Sissejuhatus}

Kui kana laulab, läheb kodu hukka.

Kolm aastat kurdina, kolm aastat tummana.

Need vanasõnad iseloomustavad tabavalt naiste seisundit Korea ühiskonnas. Esimene räägib sellest, et naistel oli keelatud kodus suud lahti teha, olles selgeks naiste eneseväljendusõiguse eiramise näiteks. Teine vanasõna jagab abielunaisele õpetust tema saatuse kohta: mehe kodus peab ta elama nagu kurt ja tumm, kes ei oska rääkida ega kuule midagi. Nagu need vanasõnad näitavad, ei olnud naistel lubatud oma soove ja õigusi väljendada ning nad elasid kogu elu justkui vangidena omaenda kodus. Ühesõnaga: naiste osaks langesid vaid kohustused, mitte aga õigused. Veel 20. sajandi alguses polnud naistel võimalust ühiskonnas kõrgemale astmele tõusta ja end harida ning konfutsianistliku elukorralduse tõttu oli Korea naiste elu võrreldes meestega palju piiratum.

Enamik tuntud tegelasi Korea ajaloost on mehed, naisi on kuulsate nimede hulgas hirmuäratavalt vähe. Naised, keda austati, olid ühiskondlikule rühmitusele truud heade abikaasade või emadena. 
Ei saa aga öelda, nagu poleks Korea ajaloo jooksul naiste seas märgata mingisuguseid pingutusi oma olukorra parandamiseks ja ühiskondliku rolli saamiseks. Eriti silmapaistev on naiste loodud (tänapäevalgi populaarse) väärtkirjanduse hulk. Ent siiani ei teata nendest kirjanikest suurt midagi, sest nad on saanud tuntuks kellegi teise nime või pseudonüümi all. Oli naiskirjanikke, kes sooritasid lõpuks enesetapu või lakkasid ühiskondlike kitsenduste ja meeste karmi kriitika tõttu kirjutamast. Korea traditsiooniline ühiskond võis olla naistele äärmiselt ängistav.

Rahvaluules oli aga naiste osa hoopis teistsugune ja nende tegevus on seal silmanähtav. Folkloor kujunes vahendiks, kus eneseväljendusõiguse järele janunevad naised said järgida oma loomesundi. Kaunid laulud, tantsud ja rahvaluule, kus kõlavad ka naiste hääled, on püsiväärtused, mida pidevalt edasi antakse, ning need näitavad veenvalt naisloojate loomejõudu.

Siinkohal vaatleme üht rahvaluuležanri - müüte ehk jumalate lugusid. Koreas on tänapäevalgi käibel paeluvad legendid, muinasjutud ja vanad müüdid. Jumalate lood on kogu Koreas laialt levinud. Uurijad on juba ammu tõestanud, et müütidel on tohutu väärtus rahva vaimulaadi ja vaimutegevuse suunajana. Lisaks iseloomustavad need ühiskonda ja selle struktuuri müütide kujunemise ajal. Kui müütide algne kuju ja sisu jäid muutumatuks ajast, mil neid hakati kanoniseerima ja edasi andma, on võimalik, et korea müüdid kirjeldavad otseselt tollase klassiühiskonna struktuuri ja nägu. Korea tähtsaimates müütides ei ole kuigi palju naistegelasi. Lugudele kiiret pilku heites on selge, et enamik kangelasi on mehed ja lood jutustavad meessoost valitseja või jumaliku kangelase tegevusest. Kas jumalate maailmas elavate naiste olukord sarnanes maiste naiste omale?

Kangelane on müüdi silmapaistvaim ja austatuim tegelane. Kui vaatleme Vana-Kreeka ja Rooma kangelasmüüte ning Põhjamaade müüte jumalatest, näeme, et sealgi on kangelased enamasti mehed. Aga kindlasti esineb ka loo tegevust juhtivaid naisi, kuigi neid on meestest vähem.

Müütiline kangelane erineb põhjalikult teistest tegelaskujudest. Suulises pärimuses leidub hulk tegelaskujusid. Tegelasteks muudetakse ka paljud ümbritsevad objektid, näiteks loomad, loodus, taimestik. Kangelase tegelaskuju tuuakse noortele eeskujuks ja nood seavad eesmärgiks tulevikus kangelasi jäljendada. Just noored otsivad autoriteete kangelaste seast, sest need on rahva seas austatud riigi ja rahva juhtidena.

Võib-olla kujunes selline suhtumine seoses jumalate kummardamise ja austamisega, mis ületab tähtsuselt ja mahult tavapärase austuse. Kangelane ei ole pelgalt austuse, vaid aukartuse objekt. Aukartus kätkeb endas ka kuulekust, mis ületab riigitruuduse. Nii rahvuskangelased kui ka ammu surnud esivanemad muutuvad austuse ja kummardamise objektiks, ent kangelastele 
langeb osaks midagi enamat kui au või kombetalitus, millega neid maetakse või kuidas neid mälestatakse. Oluline on välja selgitada, miks muutub kangelane erilisemaks kui tavalised inimesed ja esivanemad, kellele saab osaks pelgalt nende pidamine pühaks või emotsionaalne austamine (Gaster 1984: 116).

Kangelast jumalustatakse üldjuhul positiivselt ja austatakse teda sügavalt kui isikut, kes oli arvukate legendide ja kirjeldatud sündmuste tunnistaja ning asus edasi meie maailmast kõrgemasse ilma või tõusis ilma lausa elavana taevasse. Korea müütilistest kangelastest esinevad sellistes lugudes Korea esimese kuningriigi asutaja Dangun ${ }^{2}$, Goguryeo ${ }^{3}$ (Eesti Entsüklopeedia järgi Kogurjo) dünastia asutaja Jumong (eesti keeles hääldub Džumong) ${ }^{4}$, Silla ${ }^{5}$ dünastia asutaja Park Hyeokgeose ${ }^{6}$ jne. Nende kangelaste iseloom ja jumalikkus erineb aga üsna palju Euroopa müütide kangelaste omast. Seda erinevust käsitletakse järgmises osas.

Kuidas on müütides kujutatud korea naisi, keda oli õpetatud elama tumma ja kurdina, ilma eneseväljendamisvõimaluseta? Kas ka müütides on naisi kujutatud vaid truude heade abikaasade ja emadena omas ühiskonnaklassis?

Minu eesmärk on analüüsida müütide struktuuri, tuua välja nende naistegelaste kangelaslikkus, mis sisendas tolleaegsetesse naistesse vaprust ja lootust, ning seeläbi tõestada, et korea müüdid pole ainult ühiskonnas valitseva olukorra passiivne peegeldus, vaid neil oli aktiivne funktsioon, mis avaldas ühiskonnale kindlat mõju ja korraldas ebaloogilist ühiskondlikku rühmitumist. Lisaks uurin korea naiste kangelaslikkust nendes ilu ja väärikust väärtustavates müütides, milles naiste tegevus on olulisel kohal.

\section{Naised korea müütides}

\section{Korea müütide üldine iseloomustus}

Korea võib oma 5000 aasta pikkuse ajalooga ette näidata tohtu varamu suulist rahvaloomingut, mille hulka kuuluvad šinhua (müüt), chonsol (legend) ja mindam (muinasjutt). Loomulikult on kogunenud hulk müüte, mis räägivad korea rahva algusaegadest ja päritolust. Seesuguseid müüte leidub igas piirkonnas ja kõigil ajalooperioodidel. Euroopa müüdid räägivad tihti jumalatest, kes elavad taevas või mingis jumalikus maailmas, mis on täiesti erinev surelike omast. Need jumalad elavad kummalises ja salapärases maailmas tundmatul ajal. Suurem osa sellistest legendidest on maa või taeva tekkimise lood. Korea müütides rõhutatakse tegelaste inimlikkust rohkem kui jumalikkust. Neis kirjeldatakse enamasti jumala ja inimeste kokkusaamisi. Näiteks tulevad jumalad alla maa peale eesmärgiga rajada riik ja hakata suhtlema inimestega 
(Butkus \& Ermanytė 1999: 104). Seega leiab loo tegevus aset maises ilmas, mitte teistsuguses jumalikus maailmas.

Lugusid jumalatest hakati Koreas kirja panema juba tuhat aastat tagasi, aga tänapäevani arutletakse nende autentsuse ja usutavuse üle. Tuntuimate korea müütide enamik on seotud esimese dünastia kuningate sündimisega, mis, tõmmates paralleele Euroopa mütoloogiaga, sarnanevad pigem legendidele.

Korea müüdid on küll väljapaistvalt ajaloolised, ent nende kangelased, nimelt kuningad, on jumalikud inimesed, ja jutu süžee käigus muutub jumalik eksistents lõpuks inimlikuks. Sel viisil sündinud kuningatele mõeldud tseremoonia elemente on üle kantud ka tänapäeva jumalateenistuse struktuuri ja sisusse. Ei eksisteeri süsteemi ega reegleid, mille kaudu saaks kogu maailma müüte ühetaoliselt vaadelda ja uurida. Soome folkloristi Lauri Honko arvates tuleb uurida, mismoodi kasutatakse müüte ühiskonnas, ja seda mitte standardiseeritud süsteemi järgi, vaid võttes arvesse piirkondlikke iseärasusi. Müüte uurides on oluline võrrelda esmajärjekorras ühiskonnarühmas jumaliku korra kehtestajaks tunnistatud maailma loomise müütide ja kosmogooniliste müütide ülesehitust. Müütide kategoriseerimine sisu järgi on võimalik ainult mingi kindla perioodi kohta ja samas kultuuriareaalis. Sellist liigitamist ei saa kasutada folkloori puhul, mis on loodud ühiskonna erinevate liikmete poolt pika aja jooksul. Žanri iseloomustamisel pole kõige olulisem müütide vorm, vaid see, kuidas inimesed neist aru saavad. Müütide mõistmiseks pole oluline mitte stereotüüp, vaid vaatepunkt - see, kuidas rahvas neisse suhtub (Honko 1984: 50). Valdavalt olengi oma käsitluses arvestanud tunnustatud teoreetikute Dan Ben-Amose (1982), Ruth H. Finnegani (1992), Lauri Honko (1984, 1989) ja Claude Lévi-Straussi (1964) käsitlusi.

Korea müüt on lugu, mis kirjeldab rahva päritolu, jumala maale laskumist ja ajaloo algust. Seega on müüt rohkem kui tavaline legend või muinasjutt, sest see räägib korea rahva elu suunast ja vaimsest alusest. Ka ei erine nende müütide struktuur oluliselt Euroopa kosmogooniliste müütide omast.

Korea müüdid saab jaotada kaheks: raamatutes avaldatud kirjalikud müüdid ja suulised müüdid. Kirja pandud müüt on enamasti seotud rahva ja dünastia asutajatega, suuline on aga eepiline müüt, mida on edasi andnud šamaanid, kes on etendanud neid oma rituaalides. Dünastia asutamise müüdid on kirjapandud Korea vana aja kroonikatesse, nagu Samguk Sagi ${ }^{7}$ ja Samguk Yusa, mis räägivad rahva või dünastia asutamise protsessist ja selgitavad ka kuningliku perekonnanime päritolu. Perekonnanimede päritolu selgitavad müüdid on iseloomulikud korea rahva tõekspidamistele, mis peavad pere ja sugulust ühiskonna aluseks. See on äärmiselt oluline ja omapärane müüdižanr. 
Šamaanilaul muga on oluline müüdižanr dünastia asutamise müütide järel. Mugasid hakati kirja panema alles 1930. aastast, kuid nende ajalugu on väga pikk. Šamaanimüüt muga kujunes muistse jumalakummardamise tseremoonia või pidustuste kaudu (umbes 2000 aastast tagasi) ja on aja jooksul elanud läbi nii õitsenguperioode kui olnud ka vajunud unustustehõlma. Tänapäevani säilinud ja edasi antud šamaanimüütide põhisisu kujunes vanade religioossete kombetalituste ja pidustuste käigus ning kujundati ümber, inkorporeerides neisse budistlike legendide elemente, samuti lugusid reaalsetest ajaloolistest tegelastest. Mõned müüdid said romaanide ja muinasjuttude allikaks. Ühesõnaga, neil on ühine allikas, kuid konkreetsete süžeede allikad ja materjalid on erinevad.

\section{Naised korea müütides}

Nagu eespool mainitud, on korea müütides ülekaalus meeskangelaste tegudega seotud lood. Meeskangelaste kõrval leidub siiski ka naisi, kuid võrreldes meestega on nende osa imeväike. Naise motiivi on enamasti kasutatud selleks, et rõhutada täiusliku perekonna ja abielu tähtsust. Korea müütidest on tuletatav arusaam, et perekonnas on kõige olulisem abikaasade suhe, mitte isa-poja suhe, ja see asjaolu on väga tähendusrikas. Abielusuhete puhul on naise koht sarnane mehe kohaga. Riigi asutamise müütide puhul on paljud süžeed seotud isa-poja suhetega, kuid see leiab oma väljundi eelkõige siis, kui tegelased asuvad otsinguretkele, et viia oma pere uuesti kokku. Süžee, kus kuningapoeg võtab ette teekonna, leidmaks oma isa, esineb korea müütides samuti tihti. Aga kangelasest (nimelt mehe ja naise abielu tulemusest) jutustava loo ülesehitusest põhilisima osa moodustab jutustus kangelase sünnini viinud juhtumitest ja asjaoludest, mis on tähtsamal kohal kui jutustus kangelasest endast. Näiteks, kui müüt jutustab tegelasest A, siis jutustuse osa, mis on seotud otseselt A tegevusega, on müüdi kõige viimane osa, mis kuulutab tema sündi. Põhiosa loost jutustab tema vanematest. Korea müütides esineb tihti motiiv, kus vanemad palvetavad, et neile sünniks poeg (eriti šamaanimüütides), ning taeva poolt välja valitud lapse hülgamine toob kaasa kohutava saatuse. See on oluline raamistik korea müütide struktuuris. Koreas on perekond kui ühiskonna põhialus teistest väärtustest kõrgemal. Seepärast kritiseeritakse müütides karmilt pere lagunemist, mis leiab aset liignaise ja täieõigusliku naise suhete tulemusel ja/või kõrvalnaise poja probleemide tõttu. See peegeldab kunagist ühiskonnakorda. Isegi kui naiste roll müütides ei ole eriti silmapaistev, pole neid ka halvustatud ega hooletusse jäetud.

Naissoost müüditegelase kõige iseloomulikum joon on see, et ta asub taeva ja maa ristumise punktis. Naisel on kahe maailma kohtumisel ühendaja funkt- 
sioon. Nagu eespool mainitud, on korea müütidele iseloomulik, et jutustatakse mitte maisest ilmast eraldatud teistest maailmadest, vaid taevase jumala laskumisest sellesse maailma ning järgnevast riigi asutamisest või harmoonia loomisest inimkonna ja jumalate vahel. Oluline on tähele panna, et naised etendavad kahe maailma ühendamisel kõige olulisemat rolli.

Ilmekaim näide on korea rahva esiisa ja esimese kuninga Danguni müüt. Hwanung, taevase jumala poeg, kes tuli alla maa peale, et valitseda maailma voorusega, kohtus karu ja tiigriga, kes tahtsid saada inimeseks. Hwanung käskis neil elada sada päeva, süües ainult küüslauku ja puju. Tiiger ei kannatanud sadat päeva sellist elu välja ja põgenes. Karul aga õnnestus elada sada päeva nõutud viisil ja Hwanung muutis ta naiseks nimega Ungnyeo. Ungnyeo tahtis poega ja seepärast muutis Hwanung end meheks ning abiellus Ungnyeoga. Ungnyeo ja Hwanungi poeg Dangun sai kuningaks, kes pani aluse korea rahvale. Kaks maailma ei oleks saanud ilma Ungnyeo abita ühineda vaatamata sellele, et jumal ise tuli maa peale. Kaks maailma ühinesid Ungnyeo kaudu, kes pani aluse uuele ajaloole. Seega on loomulik, et selles müüdis on Ungnyeod rohkem rõhutatud kui Danguni ennast. Ungnyeo sarnaneb selles mõttes paljude rahvaste müütilise ettekujutuse keskme maailmapuuga.

Naise ühendajaroll ei piirdu ainult selle müüdiga. Võtame näiteks Jumongi müüdi, mis jutustab Kogurjo (Goguryeo, ühe Korea algriigi) esimese kuninga Jumongi elust. Jumongi ema, veejumala tütar Yuhwa on pagendatud maisesse ilma pärast abiellumist taevajumala poja Hae Mosuga ja ta sünnitab Jumongi, Kogurjo (Goguryeo) esimese kuninga. Yuhwa on ühendaja, kelle kaudu ühinevad taevajumal, nagu see oli ka Hwanungi puhul, ja kontrastiks veejumal. Ta on algataja, kes paneb aluse uuele ajaloole teises maailmas. Üldiselt on mehi kujutatud jumalatena, kes tulevad inimeste maailma, naised aga on selle maailma elanikud. Mõnevõrra erinev on aga Cheju saare Samsongi müüt, mis jutustab kolmest naisest, kes saadetakse juba sellel saarel sündinud kolmele jumalikule mehele (Seo 1980: 50). Need kolm jumalikku meest, ehkki nad ei laskunud taevast, olevat tõusnud maa alt ega erine põhimõtteliselt taevajumalatest. Kolm naist on saadetud tundmatutest naaberriikidest, et nad jumalatega abielluksid, seega etendavad nad ka selles müüdis samalaadset maa ja taeva ühendaja rolli nagu Ungnyeo ja Yuhwa.

Korea müütides ühendajarollis olevate naiste seisund pole selgelt ja üheselt tajutav, kuid seda saab võrrelda Jeesuse rolliga looja (jumal) ja tema loodu (loodus) ühendamisel. Naiste ülesanne on assimileerida või ühendada vastandeid: taevas ja maa, jumal ja inimene, loodus ja inimloomus, kaos ja kord. Euroopa müütides etendavad kangelased ise taeva ja maa vahel eksisteeriva ühendaja rolli, ent korea kangelane on tavaliselt erinevate vastandite ühendamise tulemus ja nende vastandite ühendajaks on mitte kangelane ise, vaid kangelasest eraldi seisev tegelaskuju, kes tavaliselt esineb naisena. 
Oluline on välja tuua, et naiste esinemine müütides vastandite ühendajana on äärmiselt sarnane tänapäeva šamaanide tegevusega, kellel on senini mõju korea kultuurile. Kuni Jumongi sünnini on Yuhwa tegevus võrreldav šamaanide omaga: saadakse kokku jumalatega, kelle juures ilmneb saladuslik nähtus, millele järgneb ühiskonnast pagendamine ja isoleeritus. Võimalik, et nii ratsionaliseeritakse šamaani jumalikkust (Jo 1983: 50). Šamaanid on nagu preestrid, kes ühendavad sarnaselt müütide naistegelastele taeva ja maa. Seda vaadeldakse lähemalt järgmises osas.

\section{Korea müütiliste naiste iseloomujoonte analüüs}

\section{Dang-gõm-agi, printsess Bari ja Väinämöinen*}

Eelnevalt käsitlesin üldiselt naiste kujutamist korea müütides. Koreas on valitsevaks kirjasõnalised müüdid ja nendes ilmuvad naised lihtsalt passiivsete vastandite ühendajatena. On aga väga raske leida müüte, kus naisi kujutatakse iseseisvate isiksuste või kangelastena, kelle tegevus on võrreldav meeste omaga. Siinkohal soovitan lähemalt uurida mitte kirja pandud, vaid šamaanide poolt suusõnaliselt edasi antud müüte. Nagu juba öeldud, olid suusõnaliste müütide traditsiooni edasikandjateks šamaanid, kes toimisid jumala ja maa ühendajatena. Šamanismiga tegelesid tavaliselt naised ja šamaanidel oli kahekordne sotsiaalne surve: naise ${ }^{9}$ ja Korea ühiskonna kõige madalamasse klassi kuuluva inimese oma. Korea müütide hulgas on valitsevateks riigi ja dünastia asutamisest jutustavad müüdid, kuid šamaanimüütide mõju korea suulisele kirjandusele ei ole kaugeltki ebaoluline.

Käesoleva artikli selle osa uurimisobjektiks on kaks müüti, milles naiste tegevus ja mõju on üsna silmapaistvad: Chesok Bonpuri (Dang-gõm-agi) müüt ning printsess Bari müüt, mida peetakse šamaanide päritolu tõendavaks jutuks. Nende müütide väärtus ei seisne ainult asjaolus, et nad pakuvad hea ülevaate Korea möödunud ajastute olustikust ja usundist. Nad on sisuliseks aluseks korea tuntuimatele muinasjuttudele ja omavad mõõtmatut tähtsust kirjanduse ja kunsti motiivide allikana ka tänapäeval.

Chesok Bonpuri on Dang-gõm-agi elulugu. Dang-gõm-agi on surnud inimeste saatusega tegelevate Chesok-bodhisattvate ema. Selles müüdis ei erine naise funktsioon eriti palju teiste müütide naissoost tegelaskujudest. Müüt ei jutusta otse Chesok-bodhisattvate elust ega sünnist, vaid pigem nende ema Dang-gõm-agi elukäigust. Dang-gõm-agi on sarnaselt Yuhwa ja Ungnyeole müüdi keskne tegelane, sest temast saab taeva (mida sümboliseerib India) ja inimeste maailma ühendaja. Ent võrreldes teiste naistega on Dang-gõm-agi roll 
mitu korda olulisem kui teistes müütides. Ta ei ole ainult taeva ja maa ühendaja, tema kaudu ühinevad ka kolm erinevat kultuuripiirkonda - India, Hiina ja Korea. Lisaks on Dang-gõm-agid kujutatud väärtusliku omaduse - tarkuse - kehastusena: ta on andekas paljudel aladel.

Teises vaatluse all olevas müüdis on printsess Bari kangelaslikkus selgelt välja toodud ja selles loos ei ole suuri erinevusi Euroopa eepiliste kangelasmüütide struktuurist. Printsess Bari on võrreldav Euroopa müütiliste kangelastega nagu soomlaste Väinämöinen, lätlaste Lāčplēsis ja eestlaste Kalevipoeg, kes ei kõhkle minemast teise ilma või põrgusse, täitmaks oma eesmärki. Kalevalas on Väinämöinen nii ühenduslüli taeva ja maa vahel kui samal ajal ka loo keskmes. Samamoodi hõlmab Bari tegevus ja osa müüdis teiste korea müütiliste naiste rolli tagasihoidliku ühendajana, ja sellele lisandub kogu lugu juhtiva tegelaskuju funktsioon. Kõige olulisem sarnasus Printsess Bari ja Kalevala vahel: mõlemad jutustavad šamaani päritolust. Müüti printsess Barist anti edasi suuliselt ainult šamaanilt šamaanile, samamoodi nagu kalevalalaulegi olevat esitanud tietäjäd, kes elasid hajutatult Põhja-Soomes ja Karjalas. Kalevala Väinämöinen sarnaneb üllatavalt tietäjaga, müüdilauljaga, ning tietäjate roll näib sarnanevat korea šamaani rollile (Lönnrot 1999). Tietäjä tegeles loitsimise ja nõidusega, olles unelaadses ekstaasiseisundis, ning mängis äärmiselt olulist rolli soome-ugri usundi ja rahvakultuuri säilitamisel 20. sajandi alguseni. Nende laule võib tänaseni leida soome rahvaluules ja saladuslikku laulu laulev Väinämöinen on paljuski sarnane tietäjäga. ${ }^{10}$

\section{Chesok Bonpuri ja Printsess Bari struktuuri võrdlus}

Müütide telg on sarnane - erinevaid süntagmaatilisi elemente lisatakse sellele sõltuvalt müüdi taustalt. Teljel asuvad:

- täiuslik ja tugev pere,

- puudumine ja valmistamine,

- hülgamine,

- võti tagasipöördumiseks,

- proovilepanek,

- esimene tagasisaamine,

- komplikatsioon,

- teine tagasisaamine,

- lõplik naasmine täiuslikkusesse.

Kõnealuste müütide sarnane struktuur erineb oluliselt riigi asutamise ehk eepiliste müütide omast - need müüdid tegelevad enamasti pereprobleemide 
ja peresiseste lahkhelidega. Kahe näiteks valitud müüdi struktuur sarnaneb Ida- või Põhja-Euroopa kangelasmüüdi ning eepilise müüdi struktuurile, samuti esineb hulk sarnasusi Vladimir Proppi kirjeldatud imemuinasjuttude struktuuriga. V. Proppi järgi erinevad müüt ja muinasjutt sisult ainult sotsiaalse funktsiooni tõttu, kuid süžee ja motiivi järgi kuulub müüt samasse kategooriasse kui imemuinasjutt (Propp 2000: 48).

Usun, et Korea müütide nähtamatust naise kangelaslikkusest ja tema ühiskondlikust väärtusest saab detailsema ülevaate kahe näiteks valitud müüdi üldise ja iga kangelase personaalse võrdluse kaudu. Müütide kontekst on võetud teosest Myths of Korea 'Korea müüdid', mille on publitseerinud nende koguja professor Seo Dae-seok 2000. aastal (Seo 2000). Et igast müüdist on olenevalt piirkonnast ja kogumisajast palju erinevaid variante, on võimatu neid kõiki kokku koguda ja võrrelda. Usun, et müütide erinevus tuleneb paradigmaatiliste elementide variantidest, aga struktuur jääb kõigi puhul samaks. Seepärast valisingi aluseks Seo Dae-seoki kogumiku, mis on tunnistatud kõige autentsemaks.

\section{Täiuslik ja tugev pere}

See element on seotud kangelase sünniga. Dang-gõm-agi ja printess Bari sünnivad mõlemad rikastes oludes printsessi ja tähtsa üliku järglasena. Rahva kõige suurema juhi tütrena sündinud Dang-gõm-agi ei tunne millestki puudust. Tal on pere, vanemad ja vennad. Bari sünnib printsessina Ogu riigis, mille asukoht on teadmata. Seega on tegelaste kodused olud sarnased.

Iga müüdi lõpuks on ette nähtud täiusliku olukorra taastamine, kuid see ei ole täiuslikkus ja terviklikkus ainult pere tähenduses. Dang-gõm-agi müüdis jutustatakse pikalt Sakyamuni sünnist ja Dang-gõm-agi sünnile eelnevatest asjaoludest. Niimoodi valmistatakse ette Sakyamuni ja Dang-gõm-agi suhet. Müüdi algusosa kirjeldus Sakyamuni sünnist ja kasvamisest on sama oluline kui jutustus Dang-gõm-agist. Tegelaste võrdlemine näitab, et nad ei kuulu sellesse maailma, vaid taevasesse, jumalikku maailma, seega on nende sünni taust tavainimese omast erinev. Saab öelda, et täius, mille poole Dang-gõmagil tuleb püüelda, ei ole lihtsalt oma pere tagasisaamine, vaid Sakyamuniga kohtumine, mis oli otsustatud juba enne Dang-gõm-agi sündi. Nagu siit järeldub, on pere täiuslikkus ainult esimene tase, millele järgneb tõsine probleem enne lõpplahenduseni jõudmist.

Dang-gõm-agi isa on ülik, kes on saadetud Hiinast Koreasse ja valitses Koread. Selline võimusuhe pole aga kirjeldatav kui Hiina tallalakkumine. Selline element esineb tihti teistegi rahvaste müütides oma õigusjärgluse tõendamise vahendina. Ka Euroopa müütides on palju selliseid elemente, mille kau- 
du tõendatakse oma riigi õiguspärasust ning põlvnemist Rooma keisritest, tolleaegsetest kultuuri suurkujudest ja standardist. Vastava elemendi kasutamine näitab, et Dang-gõm-agi perekonna päritolu ei ole piiratud ainult Korea poolsaarega, vaid see pärineb Kirde-Aasia kultuurilisest õigusjärgsusest.

Müüdi alguses kirjeldatakse Sakyamuni päritolu ja tausta. Ta on India, budismi seaduspärase riigi kuninga järglane ja konteksti järgi ka budismi rajaja Sakyamuni $^{11}$ ise, kuid tema eluolu on korealik. Seda müüti lugedes on väga raske ette kujutada india kultuuri või selle riigi elanike eluolu. India printsessi motiivi on kasutatud selleks, et rõhutada kultuuri seaduspärasust. Seega on selle müüdi süžee India (budismi seaduspärane riik) ja Korea (riik, kus loodi budismist uus kultuur) kohtumine. Võib öelda, et selles müüdis otsitakse usulist ja vaimset, mitte ainult perekondlikku või riiklikku täiuslikkust.

Ka printsess Bari müüdis esineb Sakyamuni tegelaskuju. Ent kui Danggõm-agi müüdi Sakyamuni on jumalik isik, kellel on salapärane või imetabane vägi ning kes on lihtsalt nimetatud budismi rajaja järgi, siis Bari müüdi Sakyamuni on üsna lähedal tõelisele Buddhale.

\section{Puudumine ja valmistamine}

Vladimir Proppi järgi moodustab imetabaste ja salapäraste elementidega imemuinasjuttudes kõige olulisema osa millegi puudumine (printess Bari perel puudub laps, Dan-gõm-agi müüdis puudub tütar). Millegi puudumisest üksi ei piisa. Probleem saab alguse, kui tegelaskujud hakkavad mõistma puudusega seotud probleeme. Enamasti võtavad tegelased või kangelased ette teekonna, et puuduv leida/saada (Propp 2000: 99).

Dang-gõm-agi müüdis on peres juba piisavalt palju printse, aga probleemiks on tütre puudumine. Printsess Bari puhul algab probleem sellest, et puudub poeg, kes riigi päriks. See motiiv esineb ka Dang-gõm-agi müüdi alguses, Sakyamuni sünni kontekstis.

Millegi puudumine ja selle saamise vajadus on see, mis ei lase saavutada täiuslikkust. Nii kujuneb kindel ja kohustuslik eesmärk, mille poole kangelased peavad püüdlema - luua täiuslik perekond, millele omistati kultuuris keskne positsioon. Kirjeldatud vajakaolek oli kahele naiskangelasele juba kõrgemalt ette määratud, et nad saabuksid lõpp-punkti nagu algkohale. Siit tulenevad ka nende kangelastegude ja käitumise motiivid.

Unenägu, mida vanemad näevad enne tegelaskuju sündi, räägib tema puudumisest. Mõlema tegelaskuju vanematele saadetakse see unenägu tänu rasedusele. Dang-gõm-agi peab tulema sellesse maailma taevase haldjana, kelle saatuseks on mingi süü tõttu uuesti sündida, ning see, et tema vanemate peres on keegi puudu, annab taevasele haldjale võimaluse juba ammu ette val- 
mistatud uuestisünniks. Antud olukorda saab võrrelda kangelase olukorraga, kes on sündinud teatud erilise ja salapärase eesmärgiga, sest ta on saadetud teisest ilmast.

Bari saladusliku sündimisega on seotud Sakyamuni. Printsessi sünd rõhutab korea müütides tihti esineva täiuslikkuse taastamise vältimatust. Printess Bari müüdis hoiatasid ennustajad ettemääratud plaani eest, aga printsessi isa Ogu kuningas ei võtnud nende ennustusi kuulda ja korraldas pulmad vastavalt oma soovile. Iga kord, kui tema naisel ilmnesid raseduse nähud, palus ta uut ennustust, kuid sisimas siiski mõistis ettemääratust. Ometi eiras ta tarkade ennustusi, mille tagajärg oli nii kohutav, et hüljatud printsess lahkus põrgusse. Siin kuuleme, kuidas šamaanid naeruvääristasid kuningat ja aristokraate, kes tegid näo, nagu ei järgiks nad šamanismi, aga tegelikult järgisid, ning see on otsekui šamaanide hoiatus Korea ühiskonnale.

\section{Hülgamine}

Kahe müüdi ühismotiiviks on ka hülgamine. Kõigi rahvaste müütides karastuvad kangelased paljude raske katsumuse läbi ja võitlemine on mitte ainult müüdi, vaid kogu suulise kirjanduse tavapäraseks sisuelemendiks. Joseph Campbelli järgi on perekonnast lahkumise ning eraldumise aluseks fookuse radikaalne muutus välismaailmast sisemisse maailma. Kangelased eraldavad end saladuste tundmatusse maailma (Thury \& Devinney 2005: 137).

Kuningas hülgab Bari kohe pärast sündi, sest peres on juba kuus tütart. Hülgamise tulemusena hakkab printsess elama teises maailmas. Dang-gõmagi hüljatakse elu jooksul kaks korda. Lapsepõlves saadetakse tema isa ja vennad intriigi tulemusena pagendusse ja seejärel lahkub kodust ema, et palvetada pere vabastamise eest, jättes Dang-gõm-agi üksi. Dang-gõm-agi eemaldumine perest ei erine printsess Bari hülgamisest. Lisaks sünnib Dang-gõmagil pärast Sakyamuniga kohtumist laps ja ta leiab end vangistatuna koopasse, sattudes olukorda, mis on senisele täiesti vastupidine. Vangistuse ja hülgamise vahele võib asetada võrdusmärgi, sest mõlema sisuks on eraldumine.

Dang-gõm-agil õnnestub eraldatuse tõttu saada taas kokku Sakyamuniga. Printsess Bari puhul tekitab kokkusaamine Sakyamuniga, kes juba eeldas Bari pühendumust, võimaluse ettemääratud plaanile vastavate ülesannete täitmise kiirendamiseks.

\section{Tagasipöördumise võti}

Mõlema hüljatud ja teises peres kasvatatud tegelase eesmärgiks on tagasipöördumine varasemasse täiuslikku olukorda, oma pere juurde (kogu süžee 
kohaselt on teine pere ainult ajutine). Müüdi selles osas antakse kangelastele võtmed tagasipöördumiseks ja sellele järgneb teine jutustus.

Võtmed tagasipöördumiseks on kõnealustes müütides erinevad. Printsess Bari puhul pakub vanemate haigus Barile kauaoodatud võimaluse nendega kohtuda ja ta õpib Sakyamunilt, kuidas lahendada tagasiminekuga seotud probleemid. Dang-gõm-agi aga kuuleb, kuidas ta saab tagasi täiusliku pere, ning ta hakkab soovi täitmise nimel tegutsema.

Sakyamuni, kes ilmub mõlemas müüdis, erineb Vladimir Proppi kirjeldatud abistajast. Abistaja on tegelane, kes jagab kangelasele nõuandeid või õpetust maagia ja muude imepäraste jõudude kohta, mis on vajalikud kangelase ülesande lõpuleviimiseks. Kui kangelane on vastavat õpetust saanud, võtab jutustus uue suuna. Selline kokkusaamine salapärase abistajaga omab müüdi süžees suurt tähtsust ja on probleemi lahenduse põhitingimuseks (Propp 2000: 102). Euroopa imemuinasjuttude puhul on abistajate ilmumine juhuslik ja seesuguse kohtumise tõenäolisus väga väike. Mingit loogilist ahelat ei eksisteeri ja kirjeldatud kohtumine leiab müüdis aset juhuslikult (Propp 2000: 100). Mõlema näitemüüdi puhul on abistaja ilmumise põhjus müüdis määratud juba enne tegelaste sündi.

Dang-gõm-agi saatuseks on kohtuda Sakyamuniga, nagu on kirjutatud juba müüdi alguses. Sakyamunil õnnestub naisega tutvuda, sest ta leiab tolle silmatorkavalt kalligraafilise kirjanäite (Sakyamuni hüüatab kirja nähes, et see on kangelase käekiri). Bari kohtumine Sakyamuniga saab võimalikuks seetõttu, et Sakyamuni tunnistab ta erakordsete vaimuannetega naiseks.

\section{Proovilepanek}

Teekonnale asunud kangelase proovilepanek on tavaline müüdielement, mis näitab tegelase ebatavalisust. Proovilepaneku tõttu leiab kangelase laialdast tunnustamist. See on pühitsemishetk, mille järel tegelane teeb läbi uuestisünni kangelasena, kellel on isalik ja mehine iseloom (Thury \& Devinney 2005: 141).

Proovilepanek, mille Dang-gõm-agi peab läbima, oli riisi andmine vanale mungale, kelleks oli muutunud tema tulevane abikaasa Sakyamuni. See pole lihtne ülesanne. Sakyamuni nõuab Dang-gõm-agilt, et viimane heidaks endalt üliku silmakirjalikkuse ja kõrkuse. Ta õpetab naisele, et kõige olulisem pole mitte auväärsus ega jõukus, vaid südamest pühendumine. See on müüte edasi andva šamaani hääl. Dang-gõm-agi läbib proovilepaneku alles siis, kui ta loobub aristokraatlikust auväärsusest ja enesearmastusest ning pääseb järgmisele, ajutisele puuduse kõrvaldamise tasandile. Süžee kohaselt järgneb Sakyamuni korraldatud raske proovilepaneku sooritamise tõttu täiusliku pere ajutine taastumine. 
Bari käitub proovilepanekul mehiselt ja jätab maha naise häbitunde, abielludes koletisega.

\section{Esimene tagasisaamine}

Sellel tasandil tundub, nagu oleks probleem lahendatud. Tegelikult aga ilmneb uus element, mis juhib jutustuse teisele tasemele. See võrdub V. Proppi mainitud probleemi lahendamise tasemega: prints saavutab võidu võitluses draakoniga ja päästab printsessi, Väinämöinen saab hetkeks Sampo kätte. Esimese proovi õnnestunud läbimise järel ilmneb uus komplikatsioon ootamatu pöörde tõttu, mis viib lõpliku täiuslikkuseni.

Dang-gõm-agi naudib õnnelikke silmapilke, mis järgnevad vanemate vabastamisele, samas alustab ta aga uut reisi, otsimaks peamist täiuslikkust kohtumist Sakyamuniga. Ta kannab Sakyamuni poega. See on väga oluline moment, mis on teise hülgamise ja reisi alguseks.

Printsess Bari olukord on sarnane Dang-gõm-agi omale. Tal õnnestub leida ja saada enda kätte rohi, mis ta vanemad terveks raviks, ning ta abiellub Mužangiga, mille kaudu tekib uus eesmärk.

\section{Komplikatsioon}

See on aste, mis V. Proppi järgi esineb vältimatult imemuinasjuttudes. Sellel astmel pöördub müüdi tegevus ootamatu komplikatsiooni tõttu jälle tagasi algusse ja sama probleem, mida kangelane müüdi alguses juba korra lahendama pidi, kerkib tema ette veel kord (Propp 2000: 119). Bari ja Dang-gõm-agi saavad teada kogu tõe oma saatusest ning seega on antud ka uus motiiv.

See fenomen on Dang-gõm-agi puhul selgem kui printsess Bari juures. Danggõm-agi vanemad hülgavad ta veel kord, sest ta sünnitab kolm mitteoodatud last. Dang-gõm-agi ei ela enam rikka üliku tütrena, vaid vaeses urkas ja tema olukord on väga sarnane olukorraga, millesse satub pärast sündi printsess Bari. Ka Bari jäetakse hüljatuna tundmatusse maailma, aga lapse leiavad (tänu Sakyamunile) Bari vanavanemad. Asjaolu, et paar tüdruku leiab ja enda juurde võtab, on, nagu Bari kogu ülejäänud elulugugi, ette määratud. Dang-gõmagi lapsed kasvavad salapärase väe toel ja sama vägi aitab ka teda ennast.

Ka printsess Bari juures võib leida komplikatsiooni elemente. Müüdi lõpus on rida selle kohta, kuidas Bari "tuli üksinda, aga läheb tagasi üheksakesi", mis iseloomustab Bari olukorra muutust printsessist hoopis teistsuguse taseme inimeseks. Maailm, kus Bari abiellus Mužangiga, oli nagu taevas - täis eluandvaid taimi ja eluvett - koht, kus ei olnud vaja karta surma. Kui Bari tuli aga tagasi oma pere juurde, pöördus ta tagasi surelikku maailma, sisenes sur- 
ma pimedaisse koopaisse. Korea ühiskonnas on abiellumine ilma vanemate nõusolekuta väga suur patt, eriti naiste puhul. Seepärast oli Bari valmis oma üleastumise eest karistust kandma. Tema lapsed oleksid toonud põhjuse komplikatsiooniks ja andnud selleks võimaluse, aga müüt jõuab ilma segase komplikatsioonita lõpule.

\section{Teine tagasisaamine}

Kangelaste teekond jätkub pärast komplikatsiooni. Selleks hetkeks on nad uue ühiskondliku positsiooni omandamisega uuesti sündinud ja valmistuvad uueks proovilepanekuks: Dang-gõm-agi läheb Indiasse kohtuma oma mehe Sakyamuniga ning printsess Bari tuleb koos mehe ja lastega tagasi surnud vanemate juurde. Selles astmes on palju elemente, mis rõhutavad nende kangelaslikkust. Dang-gõm-agi jõuab lõpuks Indiasse ning tal õnnestub kokku saada oma mehega, kes on muutunud noormeheks. Mees võtab aga naise vastu keeruliste proovilepanekutega. Indias annab Dang-gõm-agi oma lastele nimed ja Sakyamuni nimetab oma naist elutargaks inimeseks.

Dang-gõm-agi ja Sakyamuni esimene kohtumine leiab aset tänu ebatavalise käekirjaga kirjanäitele ja see motiiv kordub taas jutu lõpus. Väljendit “elutark inimene" kasutab ainult mees. Korea varasemas ühiskonnas tähendas "elutark inimene" rohkem kui lihtsalt "tark inimene". Koreas on tarkus ja teadmised inimese olulisimad omadused ja kangelaseks nimetatakse inimest, kes on äärmiselt tark ja kellel on vajalikud teadmised riigi juhtimiseks. Siit on võimalik järeldada, et müüti edasi andnud inimestel oli hinge peal soov luua uued naiskangelased, kes sobiksid tingimustega, mis valitsesid tolleaegses Korea ühiskonnas.

Ka printsess Baril avaneb võimalus kindlustada oma tulevik kuningast isa juures, mille kaudu tegelase kangelaslikkus ilmneb veel selgemini. Bari on kangelane, kes päästab oma vanemad ja riigi ning saab lisaks sellele ka rahva vaimseks juhiks, kes tõstab nad põrgust taevalaotustesse.

\section{Lõplik naasmine täiuslikkusse}

Kahe näitemüüdi tulemuseks on lõplik naasmine tõelisse täiuslikkusse. Tugev pere, mis oli Dang-gõm-agi peamine saatus, saab tõelisuseks, kui ta kohtub Sakyamuniga, tõuseb lõpuks elavana taevasse ja saab vaimudega tegelevate Chesok-bodhisattvate emaks. Siin pole aga kuigi palju erinevust naistegelastest, kes esinevad kirjapandud müütides kahe vastandi ühendajana. Dang-gõm-agi elukäigu kirjeldus struktuuriliselt printsess Bari elukäigu kirjeldusest ei erine. Kui võtta ainult müüt Dang-gõm-agist, siis selle struktuur 
on täpselt sama mis eepilistel kangelasmüütidel. Dang-gõm-agi headuse ja kangelaslikkuse rõhutamine, mis müüdi jooksul üha kordub, on mõistetav selge kavatsusena tõsta tegelaskuju esile kangelasena, kes Korea ühiskonnas puudus, ning see on märguanne ja hoiatus Korea jõuetule vanale ühiskonnakorraldusele šamaanidelt, kelle osaks oli elada ühiskondliku surve all.

Printsess Bari ei jää lihtsalt passiivseks ühendajaks, vaid saab jumalaks, kes juhib vaimud taevalaotusse, ning selles seisneb ka põhiline erinevus Danggõm-agi müüdist. Tema roll ja tegevus ületavad naiste suhtes kehtinud tüüpiliste arusaamade piirid ja on võrreldavad selliste õhtumaiste müüdikangelastega nagu Väinämöinen.

\section{Kokkuvõtteks}

Nagu juba sissejuhatuses mainitud, annavad austatud kangelane ja tema teod rahvale ja ühiskonnale käitumismudeli. Kangelase tegevus, mis on tunnistatud pühaks ja austamisväärseks, annab ühiskonna arengule õiguspärasuse. Isegi Adolf Hitler ja Kim Ir Sen (Kim Il-sŏng) kasutasid müüte, et näidata, nagu oleks kunstlikult loodud vägivallaühiskonnal õiguspärane alus. Jumalik kangelane, kes elab rahva mõtetes, loob tasakaalu ja moodustab rahva vaimse tegevuse aluse ning müüt loob ühiskonna struktuurile olulise baasi.

Korea müütides on valdavalt võetud naisi passiivsete ühendajatena, kelle funktsioon on kangelaste sünnitamine. Ent müütide hulgas, mida on edasi antud pika ajaloo jooksul, leidub neidki, mille olemus ja struktuur on sarnased Euroopa müütidele. Ehk oli selliseid müüte varem rohkemgi, ent nad on kadunud, sest Korea ühiskonna keskmes on pikka aega olnud mehed või kõrgklassi ülikud.

Müüdid naiskangelastest ei olnud ainult tolle aja Korea ühiskonna lihtsakoelised peegeldused, vaid ühiskonnas valitsenud korra vastased sõnumid šamaanidelt, kes kuulusid kõige madalamasse klassi ja elasid topeltsurve all. Nende sõnumiks oli, et kõik inimesed on sündinud võrdsetena ja ühesuguste inimlike õigustega, ning nad naeruvääristasid ülikute klassi silmakirjalikke inimesi, kes küll mõistsid šamaani hukka, ent järgisid lõppkokkuvõttes siiski tema sõnu. 


\section{Kommentaarid}

* Korea müütide sisuga saab tutvuda ajakirja internetiversioonis, kus on avaldatud Chesok Bonpuri müüdi ümberjutustus ja printsess Bari müüdi eestikeelne tõlge.

1 Artikkel on seotud Eesti Teadusfondi grandiga nr 6518.

2 Dangun Wanggeom oli praeguse Mandžuuria Liaoningi provintsi aladel ja Korea poolsaarel asuva esimese kuningriigi Tšosoni (aastail 2333?-108 e.m.a.) müütiline asutaja, kes usuti olevat taevajumala järeltulija. Kuigi Dangun viitab enamasti riigi asutaja nimele, on arvatud ka, et see oli kõikide Tšosoni valitsejate tiitel (EE 1990: 51-60).

${ }^{3}$ Kogurjo (aastail 37 e.m.a.- 668 m.a.j.) oli üks Korea kolmest varafeodaalsest riigist (EE 1990: 51-60).

${ }^{4}$ Kogurjo kuningas Jumongi (aastail 58-19 m.a.j., valitses aastail 37-19 m.a.j., eesti keeles hääldub Džumong), keda nimetati veel Dongmyeongseongwong või Dongmyeongwong, oli Korea kolmest riigist põhjapoolseima, Kogurjo, asutaja ja esimene valitseja. Gwanggaeto steelil (mis püstitati 414. a. kuningas Jangsu poolt kadunud isa mälestuseks ning mis on Kogurjo ajaloo üks väheseid säilinud algallikaid) nimetatakse teda Kuningas Chumoks (Chumo-wang). Teistes allikates esinevad tema kohta nimevariandid Jumong, perekonnanimega Go; Chumo, Sanghae, Chumong, Jungmo või Domo (EE 1990: 51-60).

5 Silla oli üks Korea kolmest kuningriigist (EE 1990: 51-60).

6 Park Hyeokgeose (aastail 69 e.m.a. - 4 m.a.j., valitses aastatel 57 e.m.a. - 4 m.a.j.) oli Silla asutaja ja esimene valitseja, ning kõigi Korea Paki hõimude esiisa (EE 1990: 51-60).

7 Samguk sagi (Kolme riigi annaalid) on vanim säilinud ajalooline ürik Korea kolme riigi ajaloo kohta (valmis 1145 . aastal ja on kirjutatud vanahiina kirjakeeles, mida kasutasid ka tolleaegsed Korea haritlased).

8 Samguk yusa (Kolme riigi memorabiilid) on Korea kolme riigi (Kogurjo, Pektše ja Silla) kohta kogutud muistendite, rahvajuttude ja ajalooteadete kogu, mis hõlmab ajajärke ja riigivõime ka enne ja pärast kolme riigi ajastut ning selle ajal. Kroonika on kirjutatud vanahiina kirjakeeles 13. sajandi lõpus.

9 Šamaaniks võis saada ainult naine. Kui mees tegeles šamanismiga, pidi ta kandma naise rõivad.

${ }^{10}$ Tietäjä kohta lähemalt vt Siikala 2002.

${ }^{11}$ Siddhārtha Gautama (hiljem nimetatud Buddha, Buddha Gautama, Buddha Šākjamuni [Sakyamuni]); eluaastad traditsioonilise dateeringu järgi 563-483 eKr) oli budismi rajaja.

\section{Kirjandus}

Ben-Amos, Dan 1982. Folklore in Context: Essays. New Delhi: South Asian Publishers Ltd.

Butkus, Alvydas \& Ermanyte, Irena Teresè (toim) 1999. Mitologijos enciklopedija 2. Vilnius: Vaga. 
EE 1990 Eesti entsüklopeedia V. Tallinn: kirjastus Valgus.

Finnegan, Ruth H. 1992. Oral Poetry, its Nature, Significance and Social Context. Indiana: Indiana University Press.

Gaster, Theodor H. 1984. Myth and Story. Dundes, Alan (toim). Sacred Narrative, Readings in the Theory of Myth. Berkeley: University of California Press, lk 110-136.

Honko, Lauri 1984. The Problem of Defining Myth. Dundes, Alan (toim). Sacred Narrative: Readings in the Theory of Myth. Berkeley: University of California Press, lk 41-52.

Honko, Lauri 1989. Folkloristic Theories of Genre. Siikala, Anna-Leena (toim). Studies in Oral Narrative. Studia Fennica 33. Helsingi: Suomalaisen Kirjallisuuden Seura, lk $13-28$.

Jo, Heungyun 1983. Hanguk ui Mu [= Shamanism of Korea]. Seoul: Jungeumsa.

Lévi-Strauss, Claude 1964. Le cru et le cuit. His Mythologiques 1. Pariis: Plon.

Lönnrot, Elias 1999. The Kalevala: An Epic Poem after Oral Tradition. Bosley, Keith (tõlk). Oxford world's classics. Oxford \& New York: Oxford University Press.

Propp, Wladimir (= Propp, Vladimir) 2000. Nie tylko bajka. Varssavi: PWN.

Seo, Dae-seok (koost) 2000. Myths of Korea. Korean studies series 4. Seoul: Jimoondang.

Seo, Dae-seok 1980. Hanguk muga ui yeonggu: Seosa muga jeseokbonpuri yeongu. Seoul : Munhak Sasangsa.

Siikala, Anna-Leena 2002. Mythic Images and Shamanism: A Perspective on Kalevala Poetry. Folklore Fellows' Communications 280. Helsingi: Suomalainen Tiedeakatemia.

Thury, Eva M. \& Devinney, Margaret Klopfle 2005. Introduction to Mythology: Contemporary Approaches to Classical and World Myths. New York et al.: Oxford University Press.

\section{Summary}

\section{Heroines in Korean Legends}

Jinseok Seo

Key words: chonsol (legend), Korea, Korean oral folklore, mindam (folktale), legend hero, Shamanism, shinhua (myth)

The article discusses the structure of Korean legends as representative of female heroism, the purpose of which was to instil courage and hope in women at the time, and thereby proves that Korean legends are not merely a passive reflection of the social situation but serve an active function of influencing the society in a particular way and arranging the illogical social organisation. In addition, the article studies the heroism 
of Korean women in legends glorifying their beauty and dignity. In Korean legends, women are mostly perceived as passive mediators whose function is to give birth to heroes. But there are also other legends, which have been passed on throughout the long history, the nature and structure of which is analogous to European legends. Perhaps there have been other such legends, but they have not been preserved owing to the fact that the Korean society has been long dominated by men or nobility.

The myths and legends are not merely simple representations of Korean society at the time, but serve as antisocial messages by shamans of the lowest social stratum, who lived under double pressure. Their message was that all people are born equal and share equal human rights, and they ridiculed the hypocrisy of the nobility, who harshly criticised shamans but eventually followed their advice. 